\title{
Metal-Free Counter Electrode for Efficient Dye-Sensitized Solar Cells through High Surface Area and Large Porous Carbon
}

\author{
Pavuluri Srinivasu, ${ }^{1}$ Surya Prakash Singh, ${ }^{2}$ Ashraful Islam, ${ }^{2,3}$ and Liyuan Han ${ }^{2}$ \\ ${ }^{1}$ International Center for Young Scientists, International Center for Materials Nanoarchitectonics, \\ National Institute for Materials Science, 1-1 Namiki, Tsukuba, Ibaraki 305-0044, Japan \\ ${ }^{2}$ Advanced Photovoltaics Center, National Institute for Materials Science, \\ 1-2-1 Sengen, Tsukuba, Ibaraki 305-0047, Japan \\ ${ }^{3}$ Center of Excellence for Research in Engineering, Materials (CEREM), College of Engineering, King Saud University, \\ Riyadh 11421, Saudi Arabia
}

Correspondence should be addressed to Pavuluri Srinivasu, pavuluri.srini@gmail.com

Received 10 March 2011; Accepted 8 May 2011

Academic Editor: Mohamed Sabry Abdel-Mottaleb

Copyright ( 2011 Pavuluri Srinivasu et al. This is an open access article distributed under the Creative Commons Attribution License, which permits unrestricted use, distribution, and reproduction in any medium, provided the original work is properly cited.

Highly efficient, large mesoporous carbon is fabricated as a metal-free counter electrode for dye-sensitized solar cells. The mesoporous carbon shows very high energy conversion efficiency of $7.1 \%$ compared with activated carbon. The mesoporous carbon is prepared and characterized by nitrogen adsorption, scanning electron microscopy (SEM), and transmission electron microscopy (TEM). The nitrogen adsorption data reveals that the material possesses BET specific surface area ca. $1300 \mathrm{~m}^{2} / \mathrm{g}$ and pore diameter $4.4 \mathrm{~nm}$. Hexagonal rod-like morphology and ordered pore structure of mesoporous carbon are confirmed by electron microscopy data. The better performance of this carbon material is greatly benefited from its ordered interconnected mesoporous structure and high surface area.

\section{Introduction}

Global energy demand is likely to increase with the expansion of economy, even though great efforts are made to increase the energy utilization efficiency. In recent years, fuel cells and solar cells have contributed remarkably for the development of renewable energy technologies. Photovoltaic cells such as dye-sensitized solar cells (DSCs) have attracted much attention as an alternative energy source for future requirements [1], which composed of porous nanostructured oxide film with adsorbed dye molecules as a dye-sensitized anode, an electrolyte containing iodide/triiodide redox couple, and a platinized fluorine-doped tin oxide (FTO) glass as the counter electrode [2-4]. DSCs have advantages over traditional Si-solar cells due to low cost, easy fabrication, and high energy conversion efficiency $[5,6]$. For additional improvement in energy efficiency and commercialization of DSCs $[7,8]$, further cost reduction is necessary. Therefore, efforts have been made to lower the production cost of DSCs by using flexible ITO-coated polyester film, metal foil [9], and organic dyes or metalorganic complex dyes [10]. In DSCs the platinum counter electrode is very crucial towards catalytic reduction of tri-iodine. But the platinum is an expensive metal and takes large portion of fabrication cost of DSCs, which retards commercialization of the process. To reduce to the cost of DSCs process various carbon materials such as carbon black [11], activated carbon [12], carbon nanotubes, porous carbon [13], and graphite [14] have been investigated as counter electrode. However, energy conversion efficiency of reported carbon counter electrode of DSCs is still low. Therefore, further enhancement of efficiency is necessary. Among the other carbon materials, mesoporous carbon materials have received much attention due to their large internal surface area and pore volume, tunable and narrow pore diameter $[15,16]$. Templated synthesis method of mesoporous carbon, which is also known as "nanocasting" has been extensively used due to the obtained material possesses uniform and interconnected 
pores. This synthetic technique involves impregnation of silica templates with an appropriate carbon source, carbonization of carbon precursor, and subsequent removal of silica. The resulting carbon is inverse replica of ordered mesoporous silica. Herein, ordered high specific surface area and large porous carbon is synthesized using large porous silica as a template and dye-sensitized solar cells properties of synthesized carbon are investigated as a metal-free counter electrode.

\section{Experimental}

2.1. Preparation of Large Porous Carbon (LPC) Counter Electrode. Ordered mesoporous carbon material referred to as LPC is synthesized by pyrolysis of sucrose inside the large porous silica (LPS) synthesized at $130^{\circ} \mathrm{C}$ using P123 surfactant. In a typical synthesis of mesoporous carbon, $1 \mathrm{~g}$ of LPS is added to a solution obtained by dissolving $0.75 \mathrm{~g}$ of sucrose and $5.0 \mathrm{~g}$ of water, and keeping the mixture in an oven for $6 \mathrm{~h}$ at $100^{\circ} \mathrm{C}$. Subsequently, the oven temperature was raised to $160^{\circ} \mathrm{C}$ for another $6 \mathrm{~h}$. In order to obtain fully polymerized and carbonized sucrose inside the pores of silica template, $0.5 \mathrm{~g}$ of sucrose, $0.06 \mathrm{~g}$ of $\mathrm{H}_{2} \mathrm{SO}_{4}$, and $5.0 \mathrm{~g}$ of water are again added to the pretreated sample, and the mixture is again subjected to thermal treatment as described above. Carbonization is performed at $900^{\circ} \mathrm{C}$ for $5 \mathrm{~h}$ under $\mathrm{N}_{2}$ atmosphere. The resulting carbon/silica composite is treated with $\mathrm{HF}$ acid (5 wt\%) at room temperature to selective removal of silica. The finally obtained mesoporous carbon paste is coated on FTO glass using doctor blade technique $[17,18]$.

2.2. Fabrication of Dye-Sensitized Solar Cell. A nanocrystalline $\mathrm{TiO}_{2}$ photoelectrodes of $20 \mu \mathrm{m}$ thickness (area: $0.25 \mathrm{~cm}^{2}$ ) were prepared by screen printing on conducting glass as previously described [19]. The films were further treated with $0.05 \mathrm{M} \mathrm{TiCl}_{4}$ and $0.1 \mathrm{M} \mathrm{HCl}$ aqueous solutions before examination [20]. Coating of the $\mathrm{TiO}_{2}$ film was carried out by immersing for $45 \mathrm{~h}$ in a sensitizer solution (N719) of $3 \times 10^{-4} \mathrm{M}$ acetonitrile/tert-butyl alcohol (1/1, $v / v)$ solution. Deoxycholic acid $(20 \mathrm{mM})$ was added to the dye solution as a coadsorbent to prevent aggregation of the dye molecules [21, 22]. Photovoltaic measurements were performed in a two-electrode sandwich cell configuration. The dye-deposited $\mathrm{TiO}_{2}$ film and a large pore mesoporous carbon on conducting glass were used as the working electrode and the counter electrode, respectively. The two electrodes were separated by a surlyn spacer $(40 \mu \mathrm{m}$ thick) and sealed by heating the polymer frame. The electrolyte was composed of $0.6 \mathrm{M}$ dimethylpropyl-imidazolium iodide (DMPII), $0.05 \mathrm{M} \mathrm{I}_{2}$, TBP $0.5 \mathrm{M}$, and $0.1 \mathrm{M} \mathrm{LiI}$ in acetonitrile.

\section{Results and Discussion}

The unit cell parameters for the LPC and LPS materials are evaluated from the XRD data, which are summarized in Table 1 . The hexagonal unit cell $\mathrm{a}_{0}$ parameter is calculated using the formula $\mathrm{a}_{0}=2 \mathrm{~d}_{100} / \sqrt{ } 3$. It was observed that the
TABle 1: Textural parameters of large pore silica and carbon materials.

\begin{tabular}{lcccc}
\hline Sample & $\mathrm{a}_{0} / \mathrm{nm}$ & $\mathrm{A}_{\mathrm{BET}} / \mathrm{m}^{2} \cdot \mathrm{g}^{-1}$ & $\mathrm{~V}_{p}\left(\mathrm{~cm}^{3} / \mathrm{g}\right)$ & $\begin{array}{c}\mathrm{dp}, \mathrm{BJH}(\mathrm{nm}) \\
\text { adsorption }\end{array}$ \\
\hline LPC & 9.02 & 1317 & 1.31 & 4.4 \\
LPS & 10.42 & 530 & 1.17 & 10.3 \\
\hline
\end{tabular}

unit cell constant of these LPC material decreases to $9.02 \mathrm{~nm}$ compare with unitcell constant of 10.42 for LPS due to structural pore shrinkage after removal of the template. Nitrogen adsorption-desorption isotherms are measured at $77 \mathrm{~K}$ on a Quantachrome Autosorb 1 volumetric adsorption analyzer. Before the adsorption measurements, all samples are out gassed at $250^{\circ} \mathrm{C}$ in the port of the adsorption analyzer. The position of the maximum on pore size distribution is referred to as the pore diameter, which was calculated from adsorption branches by Barrett-Joyner-Halenda (BJH) method. The nitrogen adsorption-desorption isotherm of LPC along with BJH pore size distribution (inset) is shown in Figure 1(a). The isotherm is of type IV and exhibited a $\mathrm{H} 2$ type hysteresis loop. As the relative pressure increases $\left(P / P_{0}>\right.$ 0.4 ), the isotherm exhibits a sharp capillary condensation step of nitrogen within uniform mesopores, where the $P / P_{0}$ position of the inflection point is correlated to the diameter of the mesopore. The BET specific surface area was obtained from adsorption branches in the relative pressure range of $0.05-0.20$. The total pore volume was estimated from the amount of nitrogen gas adsorbed at a relative pressure of 0.98 . The position of the maximum on pore size distribution is referred to as the pore diameter, which was calculated from adsorption branch by Barrett-JoynerHalenda (BJH) method. The specific surface area amounts to $530 \mathrm{~m}^{2} / \mathrm{g}$ for LPS and increases to $1317 \mathrm{~m}^{2} / \mathrm{g}$ for LPC, while the specific pore diameter decreases from $10.3 \mathrm{~nm}$ to $4.4 \mathrm{~nm}$ for the same samples. The large pore carbon LPC material possesses pore volume $1.31 \mathrm{~cm}^{3} / \mathrm{g}$, which is higher than large pore silica LPS material. The specific surface area and specific pore volume are higher for LPC than the LPS template, which facilitates for application in dye-sensitized solar cells. It is interesting to note that structural order is retained even after the removal of the template by acid treatment. The HRTEM images are obtained with JEOL JEM-2100F. Hitachi S-4800 HR-FESEM is used to observe the morphology of the material. SEM image in Figure 1(b) reveals that the LPC has hexagonal rod like morphology, which is similar to the morphology of mesoporous silica. Highly ordered linear array of pore channels and pore structure of LPC was confirmed by high resolution transmission electron microscopy (Figures 1(c) and 1(d)).

Monochromatic incident photon-to-current conversion efficiency (IPCE) for the solar cell, plotted as a function of excitation wavelength, was recorded on a CEP-2000 system (Bunkoh-Keiki Co. Ltd.). IPCE at each incident wavelength was calculated from (1), where $I_{\mathrm{sc}}$ is the photocurrent density at short circuit in $\mathrm{mA} \mathrm{cm}{ }^{-2}$ under monochromatic irradiation, $q$ is the elementary charge, $\lambda$ is the wavelength of 


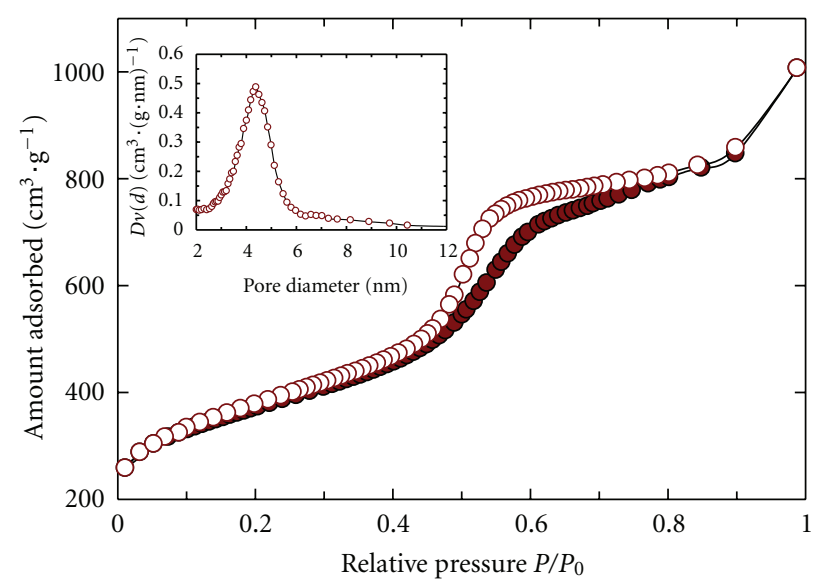

(a)

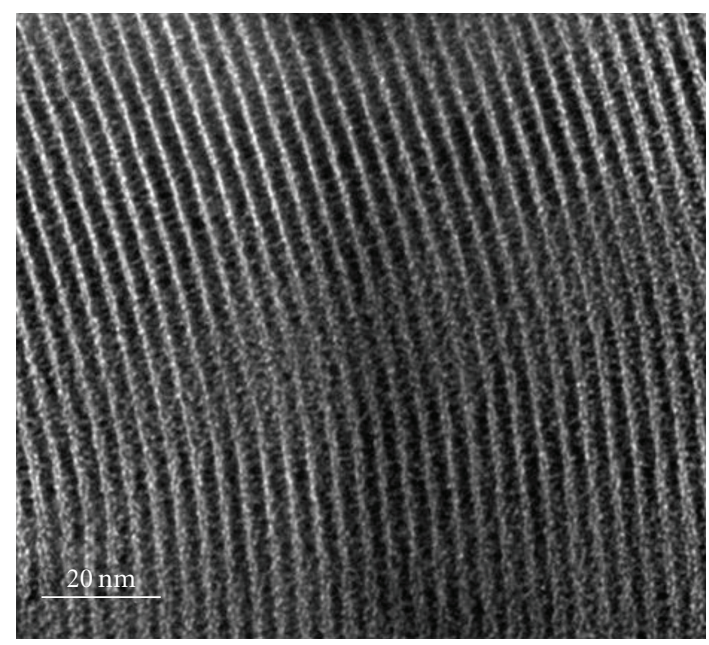

(c)

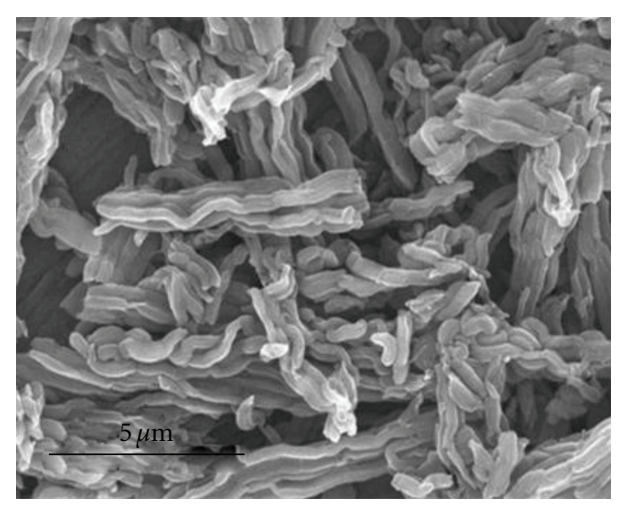

(b)

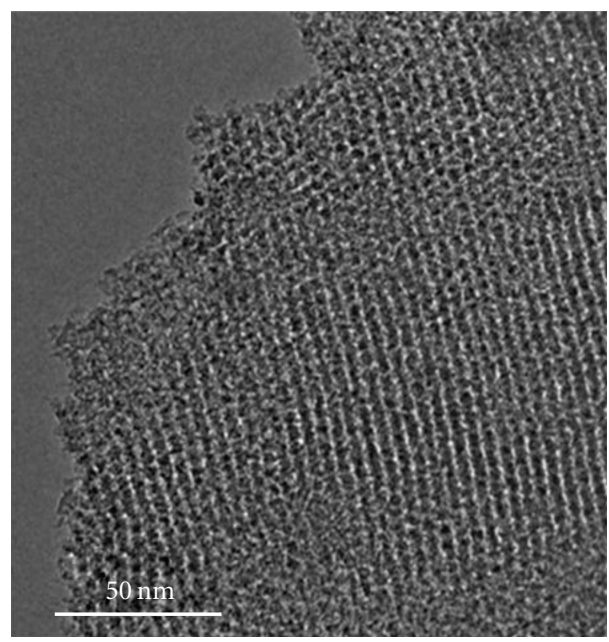

(d)

FIGURE 1: (a) Nitrogen adsorption isotherm (• adsorption, o desorption) and BJH pore-size distribution (in set) of LPC material. (b) SEM image of LPC material. (c, d) TEM images of LPC.

incident radiation in $\mathrm{nm}$, and $P_{0}$ is the incident radiative flux in $\mathrm{Wm}^{-2}$

$$
\operatorname{IPCE}(\lambda)=1240\left(\frac{I_{\mathrm{SC}}}{q \lambda P_{0}}\right)
$$

The photocurrent density-voltage curves and incident photon-to-current efficiency (IPCE) spectra of the cells are based on N719 dye under the illumination of air mass (AM) 1.5 sunlight $\left(100 \mathrm{~mW} / \mathrm{cm}^{2}\right.$, WXS-155S-10: Wacom Denso Co. Japan).

Photovoltaic performances of DSCs based on the mesoporous carbon and activated charcoal are shown in Figure 2. The short circuit current $\left(J_{\text {sc }}\right)$, the open-circuit voltage $\left(V_{\text {oc }}\right)$, the fill factor $(\mathrm{FF})$, and the overall conversion efficiency $(\eta)$ are summarized in Table 2. The results indicate that the activated charcoal shows poor performance compare with mesoporous carbon. The LPC counter electrode shows $J_{\text {sc }}$ of $12.07 \mathrm{~mA} / \mathrm{cm}^{2}, V_{\text {oc }}$ of $0.80 \mathrm{~V}$ and $\mathrm{FF}$ of $0.66 \%$ superior over $J_{\text {sc }}$ of $12.07 \mathrm{~mA} / \mathrm{cm}^{2}$, and $V_{\text {oc }}$ of $0.76 \mathrm{~V}$ and $\mathrm{FF}$ of $0.15 \%$ of activated charcoal material. The overall conversion efficiency
TABle 2: Photovoltaic parameters of DSCs based on mesoporous carbon and activated carbon electrodes.

\begin{tabular}{lcccc}
\hline Sample & $J_{\mathrm{sc}} / \mathrm{mA} \mathrm{cm}^{-2}$ & $V_{\mathrm{oc}} / \mathrm{V}$ & $\mathrm{FF} \%$ & $\eta / \%$ \\
\hline LPC & 13.41 & 0.80 & 0.66 & 7.1 \\
AC & 12.07 & 0.76 & 0.15 & 1.4 \\
\hline
\end{tabular}

achieved is $7.1 \%$ and $1.44 \%$ for LPC and AC, respectively. The higher FF and $\eta$ indicate that LPC is more efficient than AC material.

\section{Conclusions}

High surface area and large mesoporous carbon LPC with ordered pore structure has been explored as the metal-free counter electrode for DSCs. Nitrogen adsorption isotherm measurement indicates that LPC material shows very high surface area and large pore volume than mesoporous silica LPS material. SEM and TEM analyses confirm that LPC material retain morphology and order pore structure of 


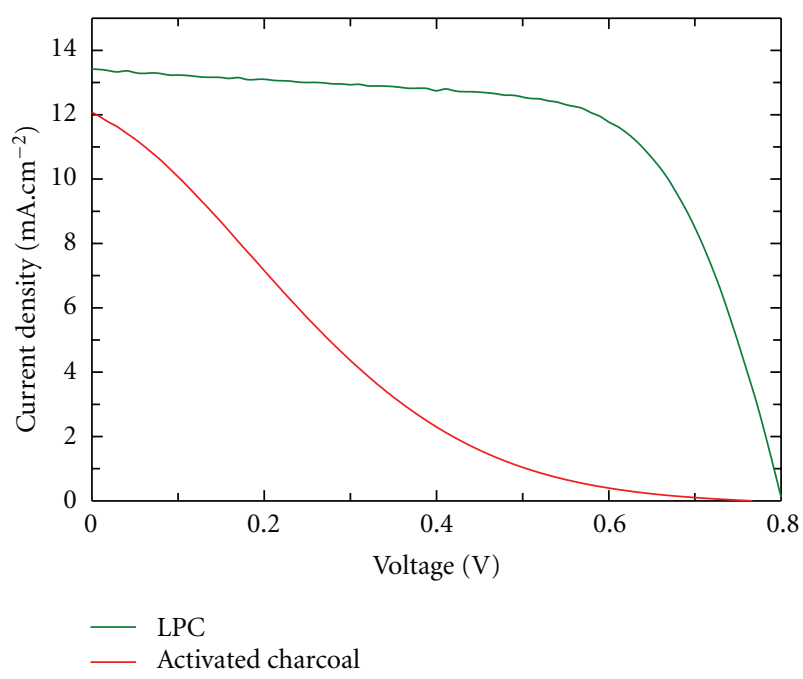

Figure 2: Photocurrent-voltage characteristics of dye-sensitized solar cells of LPC and activated charcoal materials.

the template LPS even after acid treatment. Large porous structure of LPC helps for the penetration of electrolyte and high-specific surface area of ca. $1300 \mathrm{~m}^{2} / \mathrm{g}$, interconnected pore structure facilitate for high energy conversion efficiency than activated charcoal.

\section{Acknowledgments}

The author P. Srinivasu thanks the International Center for Young Scientists (ICYS) and International Center for Materials Nanoarchitectonics (MANA) at National Institute for Materials Science, Tsukuba, Japan for financial support.

\section{References}

[1] M. S. Dresselhaus and I. L. Thomas, "Alternative energy technologies," Nature, vol. 414, no. 6861, pp. 332-337, 2001.

[2] M. Grätzel, "Photoelectrochemical cells," Nature, vol. 414, no. 6861, pp. 338-344, 2001.

[3] J. Bisquert, D. Cahen, G. Hodes, S. Rühle, and A. Zaban, "Physical chemical principles of photovoltaic conversion with nanoparticulate, mesoporous dye-sensitized solar cells," Journal of Physical Chemistry B, vol. 108, no. 24, pp. 8106-8118, 2004.

[4] A. B. F. Martinson, T. W. Hamann, M. J. Pellin, and J. T. Hupp, "New architectures for dye-sensitized solar cells," Chemistry: A European Journal, vol. 14, no. 15, pp. 4458-4467, 2008.

[5] M. K. Nazeeruddin, A. Kay, I. Rodicio et al., "Conversion of light to electricity by cis-X2bis $\left(2,2^{\prime}\right.$-bipyridyl-4, $4^{\prime}$ dicarboxylate)ruthenium(II) charge-transfer sensitizers ( $\mathrm{X}=$ $\mathrm{Cl}^{-}, \mathrm{Br}^{-}, 1^{-}, \mathrm{CN}^{-}$, and $\mathrm{SCN}^{-}$) on nanocrystalline $\mathrm{TiO}_{2}$ electrodes," Journal of the American Chemical Society, vol. 115, no. 14, pp. 6382-6390, 1993.

[6] Y. Chiba, A. Islam, Y. Watanabe, R. Komiya, N. Koide, and L. Han, "Dye-sensitized solar cells with conversion efficiency of 11.1\%," Japanese Journal of Applied Physics, vol. 45, no. 24-28, pp. L638-L640, 2006.

[7] S. Ito, P. Liska, P. Comte et al., "Control of dark current in photoelectrochemical $\left(\mathrm{TiO}_{2} / \mathrm{l}^{-}-\mathrm{I}_{3}{ }^{-}\right)$and dye-sensitized solar cells," Chemical Communications, no. 34, pp. 4351-4353, 2005.
[8] M. A. Green, "Recent developments in photovoltaics," Solar Energy, vol. 76, no. 1-3, pp. 3-8, 2004.

[9] M. Dürr, A. Schmid, M. Obermaier, S. Rosselli, A. Yasuda, and G. Nelles, "Low-temperature fabrication of dye-sensitized solar cells by transfer of composite porous layers," Nature Materials, vol. 4, no. 8, pp. 607-611, 2005.

[10] D. P. Hagberg, T. Edvinsson, T. Marinado, G. Boschloo, A. Hagfeldt, and L. Sun, "A novel organic chromophore for dyesensitized nanostructured solar cells," Chemical Communications, no. 21, pp. 2245-2247, 2006.

[11] T. N. Murakami, S. Ito, Q. Wang et al., "Highly efficient dye-sensitized solar cells based on carbon black counter electrodes," Journal of the Electrochemical Society, vol. 153, no. 12, pp. A2255-A2261, 2006.

[12] S. R. Jang, R. Vittal, and K. J. Kim, "Incorporation of functionalized single-wall carbon nanotubes in dye-sensitized $\mathrm{TiO}_{2}$ solar cells," Langmuir, vol. 20, no. 22, pp. 9807-9810, 2004.

[13] G. Wang, L. Wang, and S. Zhu, "Improvement of the photovoltaic performance of dye-sensitized solar cells by using mesoporous carbon in polyvinylidene fluoride/1-methyl-3hexylimidazolium iodide gel electrolyte," Advanced Materials Research, vol. 156-157, pp. 1078-1081, 2011.

[14] K. Imoto, K. Takahashi, T. Yamaguchi, T. Komura, J. I. Nakamura, and K. Murata, "High-performance carbon counter electrode for dye-sensitized solar cells," Solar Energy Materials and Solar Cells, vol. 79, no. 4, pp. 459-469, 2003.

[15] R. Ryoo, S. H. Joo, M. Kruk, and M. Jaroniec, "Ordered mesoporous carbons," Advanced Materials, vol. 13, no. 9, pp. 677-681, 2001.

[16] S. Jun, S. H. Joo, R. Ryoo et al., "Synthesis of new, nanoporous carbon with hexagonally ordered mesostructure," Journal of the American Chemical Society, vol. 122, no. 43, pp. 10712$10713,2000$.

[17] I. M. Arabatzis, T. Stergiopoulos, M. C. Bernard, D. Labou, S. G. Neophytides, and P. Falaras, "Silver-modified titanium dioxide thin films for efficient photodegradation of methyl orange," Applied Catalysis B, vol. 42, no. 2, pp. 187-201, 2003.

[18] R. E. Mistler, "Tape casting. The basic process for meeting the needs of the electronics industry," American Ceramic Society Bulletin, vol. 69, no. 6, pp. 1022-1026, 1990.

[19] M. K. Nazeeruddin, P. Péchy, T. Renouard et al., "Engineering of efficient panchromatic sensitizers for nanocrystalline $\mathrm{TiO}_{2}$ based solar cells," Journal of the American Chemical Society, vol. 123, no. 8, pp. 1613-1624, 2001.

[20] Z. S. Wang, T. Yamaguchi, H. Sugihara, and H. Arakawa, "Significant efficiency improvement of the black dye-sensitized solar cell through protonation of $\mathrm{TiO}_{2}$ films," Langmuir, vol. 21, no. 10, pp. 4272-4276, 2005.

[21] M. Ikeda, N. Koide, L. Han, A. Sasahara, and H. Onishi, "Scanning tunneling microscopy study of black dye and deoxycholic acid adsorbed on a rutile $\mathrm{TiO}_{2}(110)$," Langmuir, vol. 24, no. 15, pp. 8056-8060, 2008.

[22] Z.-S. Wang, Y. Cui, Y. Dan-oh, C. Kasada, A. Shinpo, and K. Hara, "Thiophene-functionalized coumarin dye for efficient dye-sensitized solar cells: electron lifetime improved by coadsorption of deoxycholic acid," Journal of Physical Chemistry C, vol. 111, no. 19, pp. 7224-7230, 2007. 


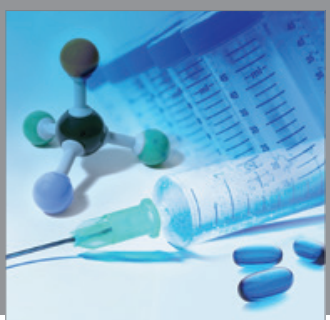

International Journal of

Medicinal Chemistry

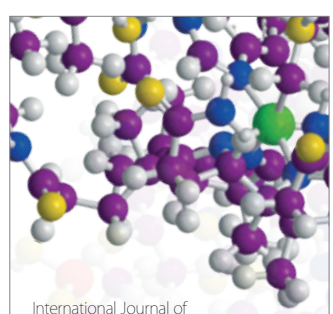

Carbohydrate Chemistry

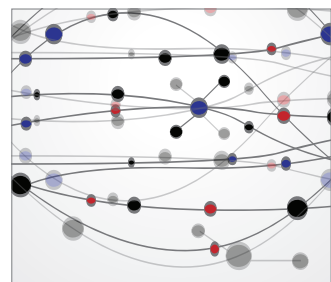

The Scientific World Journal
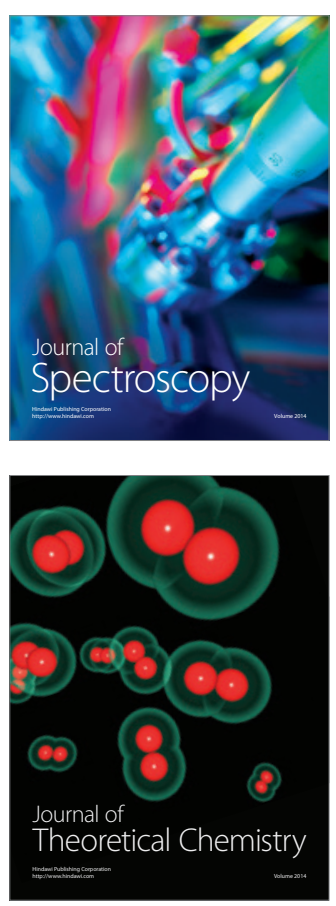
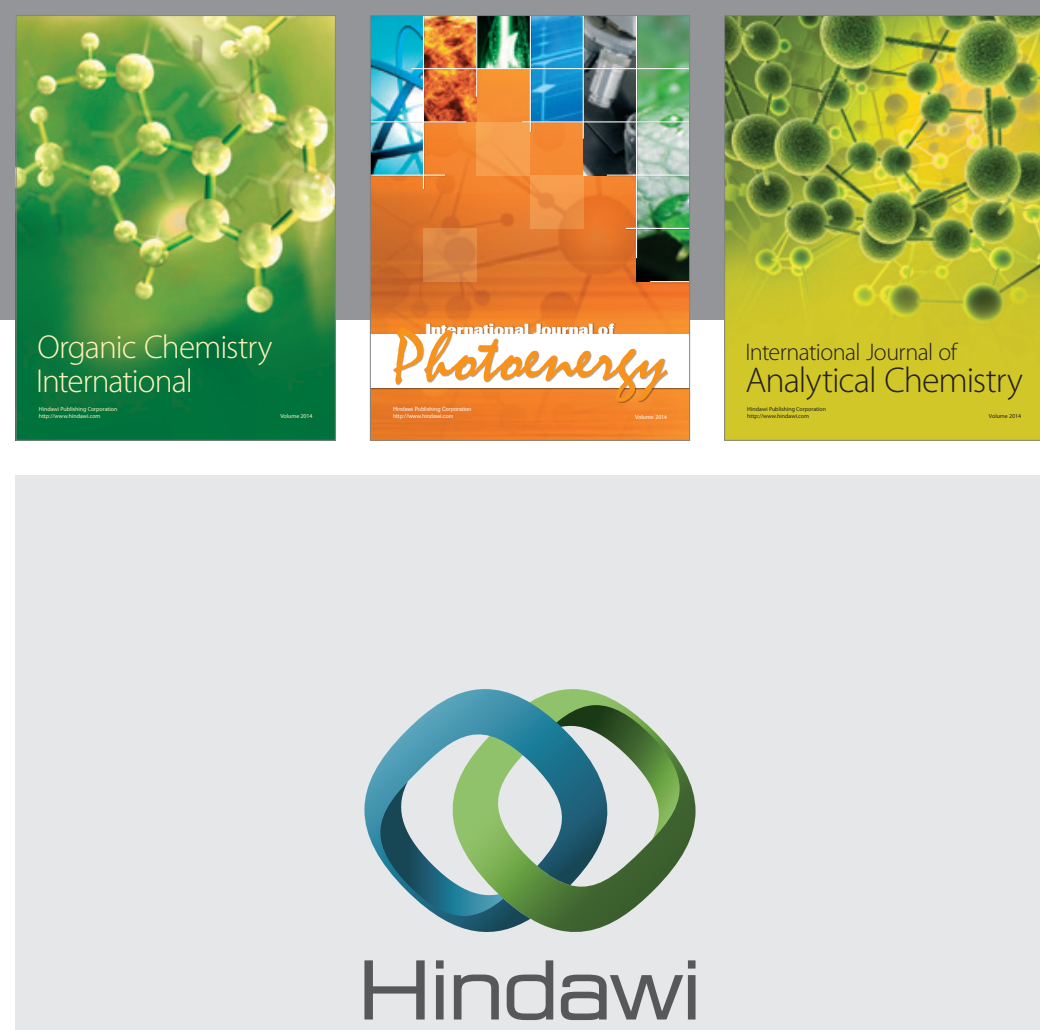

Submit your manuscripts at

http://www.hindawi.com
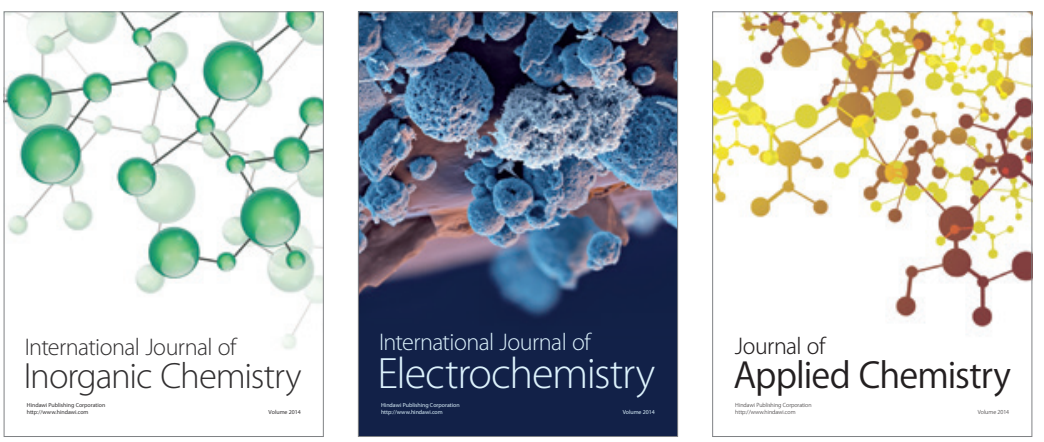

Journal of

Applied Chemistry
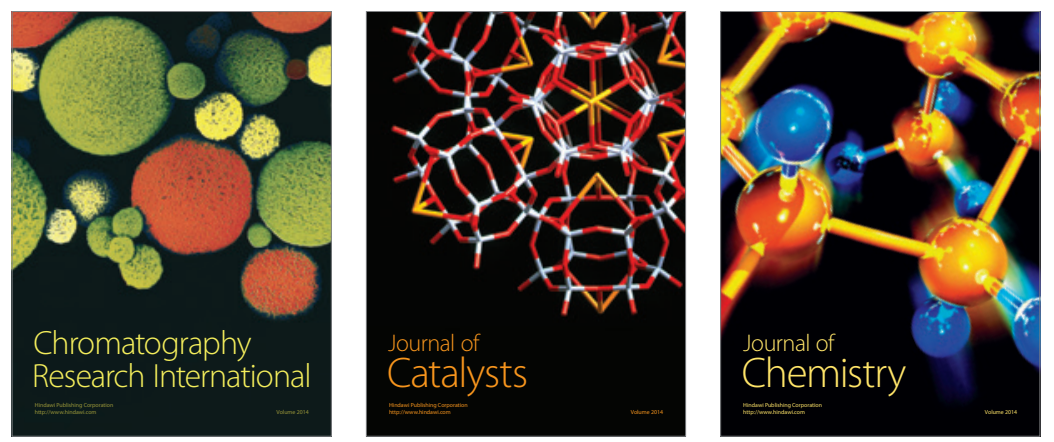
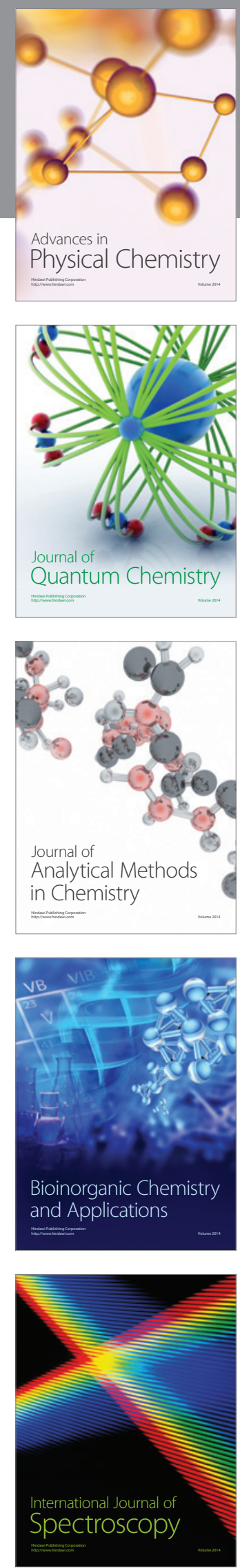